\title{
Healthcare professionals on the move: Investing in learning a new language for work
}

\author{
NÓRA SCHLEICHER ${ }^{1}$, MINNA SUNI ${ }^{2}$ \\ Budapest Metropolitan University', University of Jyväskylä ${ }^{2}$
}

\begin{abstract}
This article investigates the interrelationship of migration and language in the context of the migration experience of healthcare workers migrating from Hungary to Finland and Sweden and becoming speakers of Finnish or Swedish in the process. A nexus analytical approach is applied in studying the investment of the healthcare workers in learning a new language for work. The analysis is based on interviews made with individuals either participating in or facilitating labour migration. The findings show that the investment in learning a new language in a labour migration context is intertwined with the migration decision itself, and the migrants usually realise a return on this investment while becoming legitimate second language speakers and community members. Individual life histories, global recruitment practices, language policies and language ideologies influence the process. The communicative situations at the workplace play a crucial role in reconstructing professional identities in this context.
\end{abstract}

Keywords: labour migration; second language; investment; working life; nexus analysis; Hungarian; Finnish; Swedish 


\section{Introduction}

The migration of Hungarian healthcare workers has long been part of the public discourse in Hungary. It is framed as a serious problem that threatens the normal functioning of the healthcare sector in the country. No precise information exists on the number of healthcare workers leaving the country each year (Hárs \& Simon 2016). Estimates can be made based on statistical data of those who apply for recognition of their qualification by the Hungarian authorities to be able to work abroad (Ministry of Human Resources 2018). Between 2010 and 2018, there were on average 932 applications by medical workers (including both Hungarians and foreign citizens educated in Hungary, as well as multiple applications per person).

In 2018, the most popular target country of Hungarian heathcare workers was Germany, followed by the United Kingdom, Austria, Switzerland, Sweden, Ireland, Spain, Romania, Finland and France. English and German are the two most widely spoken foreign languages in Hungary, and Romania has a large Hungarian-speaking minority. Swedish and Finnish, however, are not commonly spoken in Hungary, so learning them requires a conscious decision and investment.

All Nordic countries suffer a workforce shortage in the health sector, but there are no quite comparable nor updated statistics available on the authorisation and recruitment of international professionals. In Finland, $9 \%$ of all medical doctors have a foreign background, and some 600 internationally educated professionals are licensed annually to work as medical doctors, dentists or nurses. Most of them come from neighbouring countries Estonia and Russia, but active recruitment of health professionals from the Philippines, Spain and Hungary, for example, has also taken place (see e.g. Vartiainen et al. 2016). By 2010, Hungarian doctors shared 5th place on the list of foreign employees in Finland. Swedish healthcare organisations have hired experts from abroad even more intensively. In 2016, there were 812 Hungarian trained doctors working in Sweden (MEC 2014; OECD 2019b; NIHW 2020). 
Hungarian healthcare professionals started to enter the Nordic labour market after Hungary's EU entry in 2004. Coming from an EU country, they officially have relatively easy access to other EU countries and their labour markets. However, whereas the Hungarians heading to German- or English-speaking countries usually know the language needed at work quite well, those planning to migrate to Nordic countries have to learn a completely new language and enter their workplaces with more limited experience of second language use. The decision to migrate to any of the Nordic countries thus includes the decision to invest in learning a new work language.

Despite the language barrier, the Nordic model of organising and managing healthcare and the good reputation of the societies as a whole have attracted international professionals to the region (Haukilahti et al. 2012). Healthcare workers are also recruited from abroad through private recruiters, a practice that is sometimes challenged on ethical grounds due to its contribution to 'care drain' from less privileged countries (Kaelin 2011).

The increased global migration of health care professionals (Connell 2010; OECD 2019a) raises important social issues worth studying. Language use within the healthcare sector is one of the aspects that has received attention. Studies on the interrelationship of migration and health care have primarily focused on the language-related barriers that migrants often face in accessing the healthcare of their host country (Moyer 2013; Thomas 2016). The linguistic challenges that many migrant healthcare professionals encounter in the new environment as they struggle to become legitimate speakers of the majority language of their host country have gained less attention (but see e.g. Sarangi 2009; Andersson 2010; Paananen 2019; Tervola 2019; Seilonen, Suni, Härmälä \& Neittaanmäki 2016). Research in this area is partially rooted in the long-term research and development work in the area of language for special purposes (LSP), although it has mainly focused on field-specific vocabulary or formal registers used in particular professions and paid less attention to lower skill levels and 
workplace interactions, for example (see e.g. Newton \& Kusmierczyk 2011).

Doctors are under enormous pressure to learn the majority language of their host country, since medical processes may, to a great degree, depend on quality of communication. During these high-stakes interactions, they may experience a significant loss in their previous high level of symbolic capital. Their expert knowledge as healthcare professionals as well as the value of their native language can get partially lost in the new environment unless they feel confident in the new language (Suni 2017).

Learning a new language in adulthood is always challenging, especially so if the new language must be learnt from scratch, as it is usually the case when the majority language of the host country belongs to the smaller, less widely spoken languages in the world. The present study focuses on the perspective of those healthcare professionals who must learn such a language for work, as they invest in symbolic capital to achieve a new professional identity in the new environment (see Bourdieu 1991; Norton 2016). We pose the following questions: what are the factors influencing the individual's decision to invest in the study of a new language for work, and what mechanisms characterise the process and outcomes of this investment?

We examine the interrelationship of migration and language learning in the context of the migration experience of healthcare workers moving from Hungary to Sweden and Finland. We focus on the lived experiences (Busch 2017) and choices as narrated and accounted for by individuals participating in labour migration in this field.

We first discuss the theoretical and methodological frameworks in which the data are analysed. After introducing our research participants, we present and analyse our data through a nexus analytical framework. Finally, the key findings of the study are discussed. 


\section{Theoretical background}

Our study is informed by critical sociolinguistics (Heller et al. 2018) and the political economy of language (see e.g. Allan \& McElhinny 2017). Migration, including the migration of healthcare professionals, takes place within a context of global inequality captured in the concept of the centre-periphery relationship (see Wallerstein 2004). Economically powerful countries in the centre faced with the increased medical needs and related costs of an ageing population attract care workers from poorer countries from the semi-periphery and periphery but also limit the availability of some of the most prestigious, higher-paying jobs (Kaelin 2011). Health experts are attracted by the higher salaries and better working conditions of the centre countries, which often invest in actively recruiting cheaper labour from these territories, but they are also forced out against their wishes from their home country, due to political and/ or economic necessities. Migrants make their decisions within a context of constraints and opportunities where multiple factors influence their choices. Language is one of the factors regulating the availability of options. As Duchêne et al. (2013: 1) put it:

Language [---] is key in selection, social mobility and gatekeeping processes [---]. It is through language that the complex relationship between the material and symbolic capital of migrants is played out on a local scale, as power institutions of the nation state interact with the globalised economic order.

Access to the labour market can be regulated and limited through setting language requirements for authorisation, and labour shortages can be tackled by providing tailor-made language education. The selection of so-called good migrants, who deserve high-quality, free or state-supported language education, over so-called bad migrants, who are denied these rights, is often the result of language policies (Baba \& Dahl-Jørgensen 2013). Doctors, for example, usually belong to the first group, as their expertise is urgently needed. However, they do not constitute 
a uniform group: doctors from outside the EU, for instance, face many more obstacles in getting their expertise formally acknowledged than those who move within the EU.

In addition to macro-level policies shaped by global processes and defined by national authorities, there are also mezzo-level policies implemented by employers and language education providers, and micro-level language policies shaped and enacted by individuals and their families. The decision to invest in learning a specific language to facilitate a career abroad is a practical consequence of the intersection of macro-level, mezzo-level and individual policies.

To bridge the gap between micro-, mezzo- and macro-level phenomena (Alexander et al. 1987), we build our analysis on the concept of investment. Drawing on theories of Bourdieu (1991) and Weedon (1987), Norton Peirce (1995) introduced the concept of investment to conceptualise the relationship between language learners and the social world around them. Investment refers to the time, energy or money used to perform goal-oriented activities, such as language learning. Norton's goal was to make up for what she claimed to be deficiencies of motivation theories in SLA (second language acquisition). She argued that these theories lack interest in mechanisms of power affecting the language-learning process and rely on essentialist and static understanding of identity. In a later work, Norton (2016) takes a poststructuralist stance and argues that identities are multiple, sites of struggle and subject to change. Social identities are constructed in the here and now of everyday interactions, and investment in learning a new language is thus also an investment in social identity. Learners are positioned in various ways by the community surrounding them (e.g. as legitimate or illegitimate speakers), but they can also actively resist these positionings at times. In refining her theory, Norton (2016) introduces the concepts of imagined communities (Anderson 1983), and identities and defines investment as:

[---] a learner's commitment to learn a language, given their hopes for the future and their imagined identities. In this view, learners invest in the target language if they anticipate acquiring a wider range of 
symbolic and material resources that will increase the value of their cultural capital and social power. (Norton 2016: 476)

This definition seems to imply a high degree of agency on the part of the language learner. However, Darvin and Norton (2015: 39) also rightly emphasise, as they place investment at the intersection of identity, ideology and capital (see Figure 1), that not all imagined futures are in fact socially available futures (see also Strömmer 2016). Furthermore, Darvin and Norton (2015: 37-47) observe that imagined futures motivate investment, but access to meaningful resources may also be constrained if language learners must struggle against unequal positioning, discriminatory practices or even systemic patterns of power.

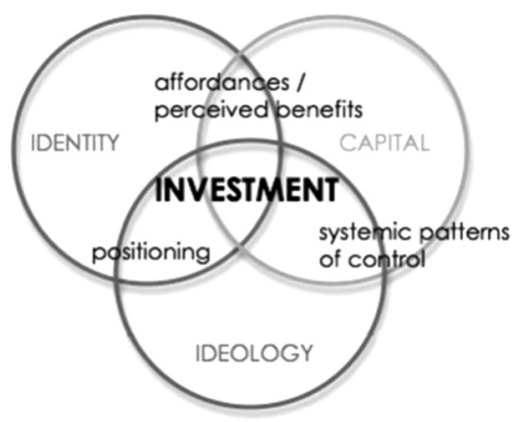

FIGURE 1. Model of Investment (reproduced from Darvin \& Norton 2015: 42)

The concept of investment will thus be employed to connect the micro, mezzo and macro levels and analyse the language and life trajectories of our research participants. Also the theoretical concepts of nexus analysis will be systematically used to bring together the different dimensions of the decisions to invest in language learning (see also Strömmer 2017). 


\section{Research methodology}

\subsection{Nexus analysis}

We apply a nexus analytical approach (Scollon \& Scollon 2004) as the general framework of our research. Nexus analysis is an ethnographically oriented, critical research orientation focusing on social action. The goal is to enter the nexus of practice and interact with participants to pin down the social actions to be studied (Lane 2014). Scollon and Scollon (2004: 159) define this nexus of practice as

the point at which the historical trajectories of people, places, discourses, ideas, and objects come together to enable some action which in itself alters those historical trajectories in some way as those trajectories emanate from this moment of social action.

The three dimensions of social action that nexus analysis combines are individual life histories and lived experiences ('historical body' in Scollon and Scollon's terminology), the discourses surrounding them in the material world, enabling or constraining action ('discourses in place'), and the 'interaction order', which is a mutually constructed communicative situation where these come together (Scollon \& Scollon 2014; see also Goffman 1983; Lane 2014). The three intersecting elements of social action are illustrated in Figure 2.

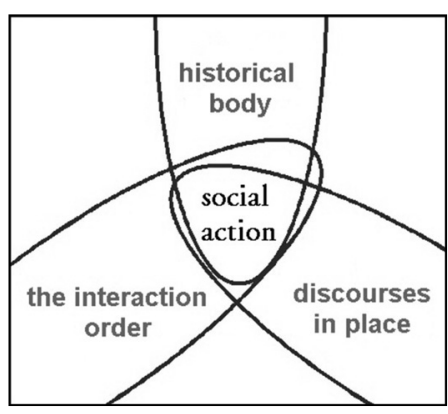

FIGURE 2. The three elements of social action (reproduced from Scollon \& Scollon 2003: 20) 
Nexus analysis allows us to capture the complexities behind the decision to invest in the study of a new language for work. Thus, the action in the focus of our analysis is this decision, which includes the interrelated actions of migration and learning the majority language of the target country.

A focus on 'historical bodies' helps us understand how the life histories of our research participants shaped their imagined and real futures and their decision to migrate and invest in a new language. A focus on 'discourses in place' shows how language policies and ideologies shape, facilitate or hinder the decision process. Finally, we study the changing social identities of our research participants by contrasting the interaction orders' characterising the language school and the old and new workplaces, as narrated and accounted for by our research participants.

All three phases of nexus analysis (see Scollon \& Scollon 2004) get covered. When engaging with the nexus of practice, the authors identified a Budapest-based, private language school as a focal point of their study. To navigate the nexus, repeated site visits were made there, and further interviews with participants were conducted in Finland and Sweden and then analysed. Both the research participants' reflections in the interviews and the reporting phase have the potential to change the nexus of practice.

\subsection{Research participants and interviews}

The focal point of the study, a Budapest-based language school (LS), was established as a private enterprise in the beginning of the 2000s to provide language courses for both Hungarians and expatriates living in Hungary. The school's website was soon discovered by Hungarian and international recruiting companies looking for healthcare professionals educated in Hungary. These professionals were contracted to work in the Nordic countries, which financially supported medical institutions to recruit workers from abroad. Before their move to the host country, these individuals were enrolled in LS's intensive language courses, which 
lasted 3-7 months and for 4-6 hours per day, and which were paid by the recruiters. The Swedish courses were more extensive than the Finnish ones; their target level was set at $\mathrm{C} 1$ on the CEFR scale (Common European Framework of Reference), while the target level for the Finnish courses was set at A2 (language education planned to be continued in Finland). Recruiters and representatives of the healthcare institutions set the target levels to be achieved in each programme and made occasional visits to the LS. Some also suggested topics for the curricula or sent authentic study materials.

The authors of this article started working on their projects independent of each other at two different points in time and joined forces after generating the first round of data. They met and recruited the research participants primarily at the LS. A group of Finnish learners and a group of Swedish learners were approached during their studies there and interviewed again when they had already gathered work experience in Finland or Sweden; on the whole, the research period spanned eight years. First, Minna Suni met a group of Hungarian healthcare specialists finishing the intensive Finnish language course before moving to Finland. She interviewed them in Hungary in 2011 and again in Finland about 18 months later when they had established themselves in Finnish working life. The participants were two medical doctors (Tamás and Tibor, males in their 40s), one dentist (Nóra, a female in her mid-20s) and a laboratory nurse (Ildikó, a female in her 40s). One more person was interviewed at the LS, but he returned to Hungary after an unsuccessful trial period. The first interviews were made in English with those participants who were fluent in it and through interpreted Finnish and Hungarian with others. The second interview round took place in Finnish, because the participants mastered it quite fluently at that point.

The next visit to the LS was made by Nóra Schleicher in 2016 when she met a group of healthcare professionals studying Swedish to reach level C1. They were about halfway through their six-month intensive training before moving to Sweden. The research participants were four male doctors in their 30s and 40s (András, Samuel, Ábel, Nándor), a 
female doctor in her 30s (Kinga, who was married with Ábel) and a female nurse in her 20s (Rita). The interviews were conducted in Hungarian; also Samuel spoke Hungarian fluently and chose this language for the interview, even though it was not his L1. These research participants were approached again in 2019, at which point they had worked in Sweden for almost four years. Two of the participants, András and Rita, responded and agreed to a second-round interview. These were conducted via a Skype video call.

Other key participants were also approached. The head of the LS was interviewed at two different times by both researchers separately. Two Swedish language teachers and one Finnish language teacher of the LS were also interviewed about their teaching experience. Finally, two Finnish medical doctors with extensive experience in recruitment and the Swedish head of a private recruiting company were asked to describe the general recruiting process from their perspective.

All the interviews $(n=22)$ were audio-recorded, transcribed and analysed with the informed consent of the pseudonymised participants. In our data examples, pauses are marked by commas, (...) refers to omitted and $[\mathrm{xxx}]$ to inaudible/unclear expressions, while transcriber's comments are marked by $\langle\ldots\rangle$. The thematic content analysis (Guest et al. 2012) was guided by our general research framework, nexus analysis (Scollon \& Scollon 2004), and focused on the concept of investment (Darvin \& Norton 2015; Norton 2016) described above.

As we present and analyse our data ${ }_{2}$ we follow the logic of nexus analysis. We start by presenting glimpses of the 'historical bodies' of the migrating healthcare professionals. Next, we briefly discuss 'discourses in place, building on narrations of language educators, recruiters and the migrant workers themselves. In this article, we place the focus on the 'interaction orders', characterising the process of migration as narrated by the healthcare workers and their teachers. 


\section{Findings}

\subsection{The historical bodies - routes of migration}

The nature of migration has changed in the last few decades and led to theorisation on transnationalism and transmigration characterising a neoliberal, globalised world of increased mobility (Levitt \& Schiller 2004; Allan \& McElhinny 2017). The life histories of many of our research participants prove the increased complexity of mobility routes. For the majority, moving to Sweden or Finland was not their first movement that could be interpreted as migration.

Some of our participants were bilinguals born and educated outside the present-day borders of Hungary, and belonged to the large ethnic Hungarian minorities living in Romania and Slovakia. Their first migration experience was thus moving to Hungary. Those participants who moved when both the country of origin and the host country were already members of the EU experienced a much smoother transition, while those who moved before that faced a longer and more complicated process.

Samuel was born in a Sub-Saharan African country and moved to Hungary after secondary school with a scholarship to study medicine. He spent his first year in the new country learning Hungarian from scratch and started his studies in medicine in that language directly thereafter. Others had spent extended periods abroad - Tamás had even worked for some months in the same hospital in Finland where he now was recruited. They all mentioned that their previous migration-related experiences made the decision easier to move abroad again. In the quote below, András contrasts the decision of his wife to stay in Hungary with his own wish to move to Sweden, and explains it with reference to their respective previous experiences.

(1) (...) de ö nem tudja elképzelni hogy kijöjjön, aki mindig otthoni környezetben nött fel, az nehezen szakad el. Ö nem tudja elképzelni ezt, hogy, de én 14 éves koromtól már nem laktam otthon (...) (András)

'(...) she cannot imagine moving away from home. It is difficult for 
someone who has grown up in a home environment to break away. She cannot imagine that. But I haven't lived at home since the age of $14(\ldots)^{\prime}$

Different past experiences create different imagined futures, leading to different decisions about migration even within the family. The first migration move was often followed by some other cross-border experience. A recurring theme in the interviews was mention of a usually brief, disappointing work experience in the UK. These participants, who spoke English well, found the experience negative due to a work culture that offers little help to newcomers. Samuel, for example, worked three months at a private hospital in England but returned to Hungary disappointed. He also applied for work in the Middle East, as he spoke some Arabic, but he found that doctors educated in Anglo-Saxon countries were preferred.

Migration is often a non-linear process. Samuel's rejection by employers in the Middle East, the brief UK experiences, and the difficulty that some trans-border ethnic Hungarian immigrants face in getting their qualifications acknowledged in Hungary prove that existing linguistic capital is not necessarily enough for a positive migration experience. Decisions to invest in a completely new language after such negative experiences are an indication of the strength of various push factors.

For our participants, the strongest push factor was their workplace experience. They talked about a workplace environment judged to be detrimental for their health, well-being and private life, due to the amount of workload, stress and responsibility, as well as a lack of material and symbolic appreciation of their work. Below, András explains how the realization that his previous working life in Hungary is not sustainable any longer was a slow, instinctive process rather than a sudden, conscious decision. This slow process was experienced as a kind of external compulsion rather than a decision based on free choice.

(2) zsúfolt volt, nagyon feszitett volt a tempó és nagy a felelősség, úgyhogy hát ö háziorvosnak nem akartam állni a három szakvizsgával (...). Az 
lett volna még egy lehetöség, de az-akkor a feleségemmel így döntöttünk, hogy inkább akkor elmegyek külföldre. Ez egy kényszer, ami így kialakult, mert én szerettem itt lakni, dolgozni csak egy idö után valamikor [xxx] egy év, két éve, ezt nem tudtam volna elképzelni, ez így kialakul, egy év alatt hogy ezt már nem lehet tovább csinálni. Furcsa dolog, ez kialakul az élet ösztönei (...) (András)

'It was very busy and the tempo was very tense and the responsibility was great so I didn't want to go and work as a general practitioner with my three specialisations (...). It would have been another option but then my wife and I decided that then I'd rather go abroad. It was a pressing need which had developed, because I liked to live and work here; only after a while at some point $[\mathrm{xxx}]$ a year, two years ago, I could not have imagined this, it develops this way, in a year, that it's impossible to go on like this. Strange thing, it develops, the instincts of life (...)

This past experience is contrasted with imagined futures in Hungary and the target country. Many of our participants mentioned that they do not expect things will change for the better in their home country. On the other hand, in the target country, they imagined a slower-paced, less stressful, more comfortable life, allowing for free time to be spent on self-development and family as well. This is how Ábel describes this goal:

(3) úgy képzeljük hogy lesz egy [xxx] kerete az életünknek tehát bemegyünk reggel dolgozni, elvégezzük a munkánkat, amit alapvetöen szeretünk, utána, ha még van kedvünk, kutatunk vagy csináljuk azt, ami ami minket még pluszban érdekel, de de mondjuk nem az van, hogy 6-kor elnézést kérek, hogy most már elnézést, de talán hazamennék, mert tényleg az ember 4 fél 5 fele jó szívvel megy haza, ahol könyvet olvas, sétál, sportol, esetleg utazik mellette, mert lesz rá pénze, utazik, mert lesz rá ideje $[x x x]$ és mondjuk kiépit egy saját életet egy olyan emberrel aki fontos neki (Ábel)

'We imagine that there will be a $[\mathrm{xxx}]$ framework for our lives, so we go to work in the morning, we do the work we basically love; after that, if we still feel like it, we do research or we do what we are interested in beyond normal work. But it is not like at six I say I'm sorry, I'm sorry but perhaps I would go home now, because really at four or half past 
four you go home with good grace where you read a book, walk, do sports; you might also travel because you'll have money, you will have time $[\mathrm{xxx}]$ and, say, build your own life with someone who is important to you.'

Investing in the learning of Swedish or Finnish is an inevitable step towards creating a reality based on these imagined futures. But this investment itself also shapes how futures are imagined. The more time and energy our research participants invest in the language, the longer time they need to spend in the new country to realise a return on this investment.

(4) Belöttünk időpontot, azt gondoljuk három [xxx] öt év az ami előbb viszszajönni nem érdemes [xxx] befektetünk rengeteg energiát és semmit nem tudunk kivenni belöle. Öt év után kapjuk meg az állampolgárságot, ha kérvényezzük, úgyhogy azt beszéltük hogy három vagy öt év után újratervezés és, meglátjuk. Most ez a terv tehát. (Ábel)

'We set a date, we thought three [xxx] five years is the time before which it is not worth returning [xxx]. We invest a lot of energy and can't get anything out of it. After five years we will get citizenship if we apply for it, so we agreed that after three or five years a new plan and then, we'll see. So now this is the plan.'

The life stories of our research participants show how individual decisions are influenced by factors of different scales, from friends and family, institutions of education and work to national policies and global politi$\mathrm{cal}$ and economic forces intermingled in a complex web. This process creates subjectivities that are well encompassed in the self-description offered by Samuel: úgy érzem magam mint nemzetközi ember, tehát, akinek van otthona és nincs otthona $[x x x]$ tehát ugye úgyérzem magam hogy mint mint egy magyarnak érzem magam mint egy < szülöföld neve > mint egy nemzetközi ember ('I feel like an international man, like someone who has a home and has no home, [xxx] you see, I feel like, I feel myself Hungarian, I feel myself < country of origin $>$, like an international man'). 


\subsection{Discourses in place}

The discursive context in which our subjects make their decisions to invest in the learning of a new language is complex. Neoliberal discourses of mobility, freedom of movement, competition and self-empowerment, for example, support their decision to invest in language learning and the related costs of migration. A language policy providing cheap and easy access to language education financed by the recruiters, often in the home country or at other cheap destinations (e.g. in Spain, a language holiday as one of our participants called it), may make one country more attractive than another. The same concerns language ideologies about the presumed 'easiness' or 'difficulty' of certain languages. As András, who ended up in Sweden, points out:

(5) (...) ha tudtam volna németül akkor Ausztriába mentem volna dolgozni menni, de (...) de németül az még úgy láttam vagy azt hallottam, hogy az egy nagyon nehéz nyelv, a német úgyhogy [xxx] a másik pedig, hogy nem, nincs ilyen beiskolázás (...) egy félév alatt (...) ők fizetnek ösztöndijat és még iskolát is fizet nekünk, erröl, ilyen lehetőségröl <köhög> nem tudok a németeknél, sem az osztrákoknál, és valahogy ott ö rosszakat hallottam a németröl, hogy nagyon nehéz, úgyhogy én azt nem akartam (...) (András)

'(...) if I had known German, I would have gone to work to Austria, but (...) but German, I thought, or I heard that it is a very difficult language, German, so that $[\mathrm{xxx}]$ and the other thing is that there is no such schooling (...), that for half a year (...) they pay you a bursary and they pay for the school too. About such things, such an opportunity <coughing > I don't know, either with the Germans or with the Austrians, and somehow I heard bad things about German, that it is very difficult, so I didn't want that.

The availability of free language education contributes significantly to migration. However, the question whether the return on the individual's investment in learning a new language can be realised or not only emerges after starting work in the new country, where various ideologies of languages and language learning also influence the process. 
In the quote below, a Finnish recruitment administrator explains how Europeans - Hungarians and Estonians, in particular - are good learners and thus preferable prospective employees for their organisation. This comment seems to get implicitly associated with the shared Finno-Ugric language background.

(6) (...) meil on eurooppaisia vähemmän, sais olla enemmän just esim unkaril- Unkari olis tosi hyvä. ne oppii tosi hyvin, emmä tiedä romanialaiset, oisko niillä samankaltanen kieli mut unkarilaisii ja puolalaisiiki (...) mut et ne on semmosii jotka on niinku, ne osaa työnsä ja on jos ne nyt vähän murtaen puhuu suomee mut ne kyllä, oppii hyvin (...) ja sit toki Viro on sitte, ihan omaa luokkaansa.

'(...) we have less Europeans, could be more, e.g. Hungar- Hungary would be very good. They learn very well, I don't know Romanians, do they have a similar language but Hungarians and also Poles (...) but those are such that they, like, know their job and if they speak a little broken Finnish but they learn well, however (...), and Estonia of course is in a league of its own.'

This data excerpt reveals how language ideologies may be intertwined with recruitment policies: certain language backgrounds are overtly preferred, and a little broken Finnish is not considered a barrier if the starting points are otherwise good. As the number of migrant healthcare workers is increasing, partially due to the subsidised recruitment and language programmes, recipient countries typically start regulating and often tightening language requirements for the healthcare professions. This gatekeeping practice can sometimes be surprisingly flexible, however, depending on the actual needs of the recipient institutions.

During the period under study, Finland required B1-level Finnish (or Swedish) language knowledge for authorisation in the healthcare sector from those educated outside the EU/EEA. Official proof of language competence from those who had obtained their degree in EU/ EEA countries, including Hungary, was not required yet. Sweden, in turn, first required B2- and later C1-level Swedish (or Danish or Norwegian) knowledge. Due to a change in the EU directive (2013/55), EU/ 
EEA-educated professionals have been required since 2016 to prove the same level of proficiency in Finnish or Swedish as others (Socialstyrelsen 2017; Valvira 2017), but this did not concern our research participants yet.

The language requirements set for healthcare workers are explained by referring, on the one hand, to patients' rights and, on the other, to equal treatment for all by abolishing the previous privileges of EU/EEAeducated professionals (MEC 2014). The major legitimising discourse behind language requirements is centred on patient safety.

As Baba and Dahl-Jørgensen (2013: 60) point out, the restrictive language policies applied in Europe can also be seen as legally and culturally acceptable ways of discouraging labour migrants' access to permanent residency or citizenship but permitting their access to temporary work. They quote Gumperz (1992), 'Discrimination on linguistic grounds may be publicly acceptable whereas ethnic or racial discrimination is not' (2013: 62). Lundström (2017) has noted that even in the officially colour-blind and immigrant-friendly Swedish society, there are evident boundaries of belonging and legitimacy to be crossed.

Not only the required level of language knowledge but also the meaning of these levels is sometimes open to negotiation, as illustrated by the following quote from the head of the LS.

(7) (...) hogyha valaki csak B1 szintet kér, akkor akkor azt ö azt a kórház vagy azért teszi, mert nagyon kevés az idö, ami rendelkezésre áll, vagy azért teszi, mert nem ért hozzá, vagy azért teszi, mert spórolni akar a költségekkel és az például nagyon nehéz, hogy azt elökészitsük, hogy ö hogy hogy ne essenek kétségbe, amikor kimegy valaki B1-es nyelvtudással, hogy hát ez nem tud olyan jól. (...) Csak ök nem értenek hozzá, nem tudja pontosan, hogy mi az hogy B1.

'(...) if someone just asks for a B1 level, then then the hospital does that either because there is very little time available or because they don't understand what it means, or because they want to save costs, and this, for example, is very difficult, to prepare them for that, so that they do not despair when someone goes there with B1 knowledge 
and, well, he doesn't know the language so well. (...) But they have no expertise with it, they do not know exactly what B1 is.'

While centrally regulated language policies prescribed higher-level language competencies for a wider scope of people, this requirement was at odds with the economic rationale of those healthcare institutions that were suffering from labour shortage and hence required urgent solutions.

The LS has prepared healthcare workers for levels ranging from A2 to $\mathrm{C} 1$, depending on the requirements of the receiving country and its authorities, hospitals and clinics. Linguistic requirements were lower in hospitals in Finland than those in Sweden, and perhaps also lower in hospitals situated farther north, which may have more difficulty securing enough workers. In everyday practice, the demand for labour may thus have overridden the preset expectations as long as the official EUlevel policies allowed it.

The investment process of our research participants was thus influenced by language ideologies, regarding the presumed ease or difficulty of learning certain languages and the presumption that certain groups of people learn better than others, and also by the language policies setting the required level of language knowledge for work. The debates around the suitable levels are a reflection of the struggle among various parties with varied and often opposing interests concerning the process.

\subsection{The interaction orders}

\subsubsection{Workplace in the home country}

All healthcare professionals in our sample had a secure workplace in their home country where their identities as professionals were wellestablished and unquestioned. Nevertheless, most of them narrated their stories in a way that suggested circumstances in the workplace played the most important role in their migration decision (see 4.1 above). Here we concentrate on the interaction orders characterising these workplaces. A recurring commonality is the highly hierarchical nature of the 
Hungarian healthcare institutions, which constrains individuals in their decision-making capacities.

(8) (...) ez a kasztrendszer, hogy voltak a nagyon öreg professzorok akik foggal körömmel ragaszkodtak a feudális jogaikhoz, volt egy alsó réteg, a szolgák, akik akik csak azért voltak hogy az apró munkát elvégezzék, és a középsö közép [xxx] réteg az egyre szürkült és szürkült, akik tudtak és akartak is dolgozni, viszont a rengeteg feladat és rengeteg felelösség között egyszer felmorzsolódtak, és aki aki nem állt be egy ilyen hát hogy is fogalmazzak egy ilyen közösségbe, egy falkába, de valami úton módon kilógott, akár gondolkodásban, akár máshogy, az abszolút perifériára került (...) (Ábel)

'(...) this caste system, that there were the very old professors who fought tooth and nail to hold on to their feudal privileges, there was a lower class, the servants who were just there to do the small chores, and the middle middle $[\mathrm{xxx}]$ layer which was turning greyer and greyer, who could and wanted to work, but then crumbled under the huge amount of tasks and responsibilities, and those who did not want to fit into one of these, how should I put it, into one of these communities, into these flocks, but were somehow sticking out of it, in their ways of thinking or in other things, they found themselves at the absolute periphery. (...)

The use of metaphorical expressions like caste system and feudal privileges suggests the existence of an interaction order defining rigid, impermeable roles, which our research participants found oppressive and hard to bear in the long run. It was contrasted by a hoped-for future workplace imagined as much more supportive.

\subsubsection{Language school}

Before leaving for Finland or Sweden, our research participants were enrolled in an intensive Finnish/Swedish language course organised in LS and paid by their future employers. During this period, they stopped working as healthcare professionals and concentrated on language learning. This meant adopting a new, temporary identity of novice learner 
where their previous professional identity and cultural capital did not count much. The interviewed Swedish language teacher commented on the difficulties faced by some students:

(9) (...) úgy érzik, hogy, hogy ők azok, akik, akiknek megmondják, hogy mit hogyan kellene, és valószínüleg az is zavarja őket, hogy korábban úgy érezték, hogy ez a szerep az övék volt mondjuk a betegekkel szemben. Tehát ezt, ezt van, aki nehezen éli meg.

'(...) they feel that that they are the ones who are being told what to do and how it should be done and probably what disturbs them, too, is that earlier they felt that this was their role, let's say, with regard to patients. So for some of them, this is difficult to experience.'

All our participants emphasise the difficulty of the task of learning a new language for work and the amount of energy they need to invest in it, but also the need to make this investment. As Kinga puts it, 'there are lots of new words and learning such a language from scratch is terribly difficult' (rengeteg új szó van és nulláról megtanulni egy ilyen nyelvet az borzasztó nehéz). In the following two excerpts, Ábel comments on the complex and ambivalent relationship of his worker/language learner identities.

(10) és nagyon nagyon sok energiát fektetünk ebbe az egészbe bele de az számomra nagyon nehéz nagyon nehéz [xxx], érdekes kihívás is, mert egészen más fajta munka, mint amit eddig csinálnom kellett, tehát az orvosi munkától, ettől a szintetizáló, logikai, ilyen kalambó szerü munkától most egészen más fajta munkát kell végezni [xxx] végig, ami nem biztos, hogy baj, kis [xxx] szellemi kikapcsolódás. (Ábel)

'And we put a lot of energy into this whole thing, but for me, it's very hard, very difficult [xxx]; it's also an interesting challenge because it's a very different kind of work compared to what I had to do before, compared to the medical work, this synthesizing, logic-based, Columbolike work, now we have to do a whole different kind of work [xxx], which may not be a problem, it is a little [xxx] mental recreation.'

Ábel contrasts language learning with his work as a doctor and also expresses his fear that the necessary investment in language learning will entail a lack of clinical practice for an extended period. 
(11) (...) másik az hogy hát azért most már lassan lassan több mint fél éve nem operáltam beteget és ez egy manuális szakma, tehát ez idő lesz míg újra visszarázódok, és újra megszokom a nagyon finom mozgásokat. Nagyon sok gyakorlást igénylö terület és hát nem egyszerü beavatkozások miatt megyek oda, tehát a szakmából való mind a manuális mind a tudásbeli kiesés is számít, ez a másik dolog amitöl egy kicsit félek. (Ábel) ' $(. .$.$) the other thing is that now it has been more than half a year that I$ haven't been operating on a patient, and this is a manual profession, so it will take a while until I get back and get used to the very fine movements again. It is a field which requires a lot of practice and I am not going there to perform easy operations, so what counts is losing out on the profession, both the manual practice and the knowledge. This is the other thing I am a little afraid of.'

Refugee medical doctors in the UK also commented on the dangers of being isolated from clinical practice for an extended time while waiting for their accreditation (Sarangi 2009: 209). Such isolation can lead to a loss of their symbolic capital, too, and can have a detrimental effect on their future job prospects.

\subsubsection{Workplace in the host country}

After arriving in their destination country, our research participants started working at healthcare institutions with various levels of language knowledge, ranging from A2 to $\mathrm{C} 1$. They now faced the challenge of re-establishing their professional identity in the new work environment. Whether they can realise a return on their investment in language learning depends on the success of this lengthy process. Before moving to Finland, Nóra asked herself: how can I manage this problem, this situation for a year now, how I can do this job? Despite already having a permanent job and quite advanced Finnish language proficiency after 1.5 years, Tamás still reflects: 'for sure I work better in Hungary because there was no language problem in Hungary' (varmasti mä teen parempi töitä Unkarissa ihan varmasti, koska ei ollut kieliongelmaa Unkarissa). The fears regarding this process are twofold. On the one hand, our research participants 
expressed empathy towards their patients, saying they should not feel the need to adjust their language use while being worried about their illness already. They also expressed worry about losing face in front of their colleagues due to not being able to make small talk, losing out on cultural references, not understanding jokes, etc.

(12) (...) de hogy az hogy nem tudod kifejezni magad a kellö módon és azt amit szeretnél mondani az általában, legalábbis nálam, az az eset szokott lenni hogy hülye vagyok (.) és nyilván ki fog vagy el fog múlni ez az érzés, csak hát az azért nyomokat hagy, tehát hogy ha most valaki beszélget van egy társalgás és legfeljebb bambán tudok mosolyogni egy ideig nem tudok hozzászólni szóval ez nehéz. (Nándor)

'(...) that you cannot express yourself in the right way, and what you want to say, in general, at least in my case, what usually happens is that I am stupid. And, obviously, this feeling is going to pass, but it leaves traces behind, so if there is someone talking, there is a conversation and all I can do is smile stupidly, and I cannot add anything for some time, well, that is difficult'.

Nándor is worried that the inability to express himself in a sophisticated way is going to be interpreted as not being intelligent enough or good enough in his field. The fear seems to be internalised as an inferiority complex. This fear of being seen as less competent due to language difficulties seems justified on the basis of the opinion of the Finnish recruitment administrator who describes some migrant doctors:

(13) tossa istuskelee sitte, kattelee ku muut tekee jotai (...) yleensä monet ei puhu mitään, ei ne niinku ota kontaktia. sit ku niilt kysyy jotain ne saa hädin tuskin vastattua. et ei se, ei ne ei ne opi sillä tyylillä ne ei opi mitään. sen sijaan jos ne tulis tänne ja kyselis kaikkee ja opettelis, ni kyllähän ne oppis.

'They are sitting over there then, looking when others are doing something. (...) usually, many of them don't say anything, they kind of don't make any contact. When you ask them something they hardly respond. So it doesn't, they don't, they don't learn that way, they don't learn anything. Instead, if they came here and asked everything and studied, they would learn, you know. 
The observed passivity of some migrant doctors, which may be partially due to their limited language proficiency, is blamed for precisely this lack of knowledge, creating a vicious circle that is hard to break. It is also easier to place responsibility on individuals than to reflect on the communication practices of the larger work community.

Finally, workplace interactions determine whether the migrant healthcare worker is accepted as a legitimate speaker of Finnish or Swedish, and whether the investment in the learning of a new language was worthwhile or not. The challenges characterising this process can relate to the difference between spoken, everyday language (e.g. local dialect) and the written standard language learned at the LS, among other things (see also Vartiainen et al. 2016). Nóra, for example, was shocked to realise upon arrival that she could not understand spoken, colloquial Finnish after having studied standard Finnish in Hungary for months, while Tamás explicated his difficulties in understanding old people speaking Finnish dialects.

Mastering the complex standards of a written language needed for documentation or when responding to complaints is yet another linguistic challenge (see Virtanen 2017), as Tibor experienced:

(14) minä, kirjoitan pari lausetta, minä opettelen potilaan asioita, katson tekstiä, siksi ei ei kielessä mut muuten loogisesti vastaan, ja sen jälkeen käännän suomeksi, suomen kieleen, ja jos se on valmis, minä menekmenen työkaverin luokse ja pyydän hänet, korrigoimaan grammatitsesi kielioppisesti tai, suomen loogisesti onko se, sanojen käyttö oikein tai väärin onko se mitä sinä sanoit kohteliainen tai tai tai raaka. (Tibor) 'I write a couple of sentences, I study the patient's case, I look at the text (that) I respond to logically although not language-wise, and then I translate it into Finnish, into the Finnish language, and if (= when) it is ready, I go to my colleague and ask him/her to correct, grammatically or according to Finnish logics, whether the use of words is right or wrong, whether what you said is polite or, or rude.'

Tibor describes intensive textual work where he reads and writes, makes translations and then asks for scaffolding from his colleagues to ensure 
that his texts are both accurate and appropriate. He shows awareness of the pragmatic aspects of health communication; misunderstandings are sometimes due to cultural differences reflected in language use. Minimising hierarchy, for example, is highly preferred in the Nordic countries, and adapting to that can be challenging at work. As one of the Swedish teachers explained: there are very few Dr Kovácses there. There, there are Peters.

Challenges can also relate to the expectation of having to become a native-like speaker. There is always something to learn even after reaching C1 level, as András' and Nóra's comments show; thus, investment in a new language is a never-ending story:

(15) Középúton vagyok a nyelvvel még három és fél év után is, azt gondolom. (András)

'I am midway with the language even after three and a half years, I think.'

(16) päivästä päivään mä huomaan että mun pitäis oppia vielä tämä ja tommonen ja ja vielä sellainen ja vielä, vielä jotain ja aina on jotain jotain pientä puuttuu. (Nóra)

'Day after day I notice that I should still learn this and that and something like that and still something, and there is always something little missing.'

In the long run, language-related stress can become such a burden that it can lead to giving up the job itself. This happened to Nóra, who left her first workplace in Finland after some months but soon found a less stressful one (see Suni 2017), and Rita, who, after working as a nurse for three years at a Swedish hospital, finally decided to take a long-term leave and started studying something else. She accounts for her decision in the following way:

(17) Hát szerintem nagyban hozzájárult az, hogy nem az anyanyelvemen végeztem, mert mindig bennem volt egy ilyen kisebbségi érzés - annak ellenére, hogy tényleg nem éreztették velem a kollégáim - én úgy bebeszéltem magamnak, hogy lehet, hogy én nem fogom tudni olyan jól megcsinálni, és akkor emiatt mindig próbáltam a maximumot nyújtani, és 
hogyha esetleg valami kis hibát csináltam, akkor azt nagyon felnagyítottam magamnak. Úgyhogy innen jött. (Rita)

'Well, I think what contributed to it to a great extent was that I didn't work in my mother tongue because I always had such a feeling of inferiority - even though my colleagues really didn't make me feel that way - I told myself that I might not be able to do the job so well and that's why I've always tried to give the maximum, and if I made perhaps a little mistake, I really magnified it for myself. So it came from here.'

Others, however, who also experienced some conflict with patients due to their non-native language skills, interpreted the situation merely as an expression of the patient's personal characteristics or a manifestation of their frustration where the language issue was simply used as an excuse.

As time passed, more and more stories about feeling successful also surfaced. As Tibor says, every day brings new words at work, but that is not a problem anymore. It has been noted in previous studies that work often serves as the key environment for language learning for health professionals (Seilonen et al. 2016 ). The availability of affordances (van Lier 2004 ) is evident in all the interviews of the current study as well:

(18) minä olen todella onnellinen mun mielestä, koska minulla ovat, todella hienoja, työkavereita. he o- he ovat, joo ihan, ihan, ihan hyviä (...) he puhuvat aina minun kanssa ja yrittivät joo tietysti puhua mutta joo heti alussa minä pelkäsin 'apua älä älä älä' (nauraen), mutta mutta mun mielestä se auttoi paljon auttoi paljon ja pikkuhiljaa minä minä ymmärsin, aina aina vähän. (Ildikó)

'I find myself really happy because I have really nice colleagues. They are quite, quite nice (...). They always spoke with me and tried to speak of course but from early on I was afraid, 'help, don't, don't don't' (laughing), but I think it helped a lot and gradually I understood, always a little.'

Thanks to scaffolding and affordances being continuously available in the working environment, professional language may even become the strongest part of one's language repertoire, leading to more confidence in one's professional identity, too. This was observed by Tamás, for example: 
(19) se oli, pari, muutaman, kuukauden jälkeen se oli ensimmäinen havainto että, ammatillisessa, piirissä meni sujui ihan hyvin, mutta oli, ihan huono, fiilis että jos sinä astuit ulos tästä, piiristä, et ymmärtänyt mitään. (...) meni puoltoist vuotta ja nyt, tapahtunut jotakin tammikuussa nyt (...) tästä lähtien minä ymmärrän, kaikki mikä tulee telkkarista, radiosta. (Tamás)

'In a couple, in some months it was the first observation that in professional circles it went all right, but it was quite a bad feeling if you stepped out of this circle, you didn't understand anything. (...) It took one and a half years and now, something happened in January (...); since then I understand everything that comes on TV, the radio.'

Tamás felt that after some months he could communicate well in Finnish at work, but not elsewhere yet. The next turning point was after one and a half years in Finland, when he realised that understanding Finnish had become fluent and effortless in some other contexts, too. Having easy access to working life is often an effective way to develop one's language proficiency and gradually reach a position as a legitimate language speaker among one's colleagues and in the language community as a whole (Ruuska 2020). The more restricted this access is, due to language policy, the more investment is needed elsewhere - such as at a language school abroad or in other types of language education programmes.

\section{Discussion}

The migration of healthcare workers has increased in recent years, resulting in a situation where more and more people work in a language other than their mother tongue. We studied this issue from the perspective of professionals who migrated from Hungary and whose new workplace is in Finland or Sweden. We aimed to find out what the factors influencing the decision to invest in the study of a new language for work are like, and what mechanisms characterise the process and outcome of this investment.

In our nexus analytical study, analysis of the 'historical bodies' revealed the important roles that material and symbolic capital and their 
unequal distribution play in the migration process. Healthcare workers on the economic semi-periphery often experience harsh working conditions and low appreciation of their work, and thus they are lured towards the centres by the better opportunities the centres can offer (see Wallerstein 2004; Kaelin 2011). Although they are not forced migrants in the basic sense of the term, the voluntariness of their decision can in some cases be questioned.

Analysis of 'discourses in place' called attention to the important regulating functions of language ideologies and language policies, which can either help or constrain our research participants. While restrictive top-down language policies such as language requirements may create obstacles for some potential migrant workers from the periphery and semi-periphery, the state-supported language education policy of the centre, sometimes concerning the same migrants, promotes international mobility and care drain, whereby highly qualified workers leave their country of origin. Discrimination can be based on and/or disguised by language requirements and ideologies that depict some languages as easier and some learners with certain language backgrounds as better than others.

Our study of the interaction orders of the old and new workplace and the language school showed how social identities are related to language learning and use throughout the migration process. The final success of the investment depends on how the healthcare workers' professional identity is constructed by themselves and by the significant actors around them. The affordances and timely support received from the closest colleagues play an important role here. A failure to realise a return on the investment in language learning is connected to an experienced loss of professional competence. (Self-)questioning of professional identity can even lead to giving up the profession itself or returning to the country of origin. However, if professional competence and the professional identity built on it are not questioned, despite the temporary shortcomings of language use, the investment proves to be worthwhile. This was the 
case with most of our research participants, who moved from Hungary to Finland or Sweden.

As future research, it would be interesting to further study the actual language use of our research participants in working situations (see e.g. Paananen 2019). However, a lack of access to healthcare institutions due to privacy concerns and related ethical issues made that impossible for us. We acknowledge this to be a clear limitation of our study. To partially compensate for this, we included several perspectives through interviews with a variety of stakeholders, such as doctors, nurses, language educators and recruiters.

The authors met and joined forces only before the second round of data collection. The resulting limitations were judged to be less significant than the advantages the cooperation offered. The increased richness of data allowed analysis along both cultural and temporal dimensions. Covering altogether a period of eight years' time provided insights into the preparation phase, with all the accompanying fears and hopes of an imagined future, and the lived reality after crossing the borders and settling down in two Nordic countries.

Nexus analysis (Scollon \& Scollon 2003, 2004) places the social action in the focus of inquiry. Our research has proved that this action in our case, the investment in learning a new language for work - is, in fact, a process without a clear starting or ending point. We would thus recommend a more emphatic inclusion of the temporal dimension in the analytical framework of nexus analysis.

\section{Acknowledgements}

Our collaboration and the study reported in this article have been facilitated by the EU COST Action IS1306 entitled New Speakers in a Multilingual Europe: Opportunities and Challenges and the research profiling project RECLAS (University of Jyväskylä) funded by the Academy of Finland. 


\section{References}

Alexander, Jeoffrey C., Bernhard Giesen, Richard Munch, Neil J. Smelser 1987. The Micro Macro Link. Berkeley: University of California Press.

Allan, Kori, Bonnie McElhinny 2017. Neoliberalism, language and migration. - Suresh Canagarajah (ed.). The Routledge Handbook of Language and Migration. New York: Routledge, 79-101. https://doi.org/10.4324/ 9781315754512-5

Anderson, Benedict 1983. Imagined Communities: Reflections on the Origin and Spread of Nationalism. New York: Verso.

Andersson, Helena 2010. Interkulturell kommunikation på ett svenskt sjukhus: Fallstudier av andraspråkstalare i arbetslivet ['Intercultural communication at a Swedish hospital: Case studies of second language speakers in a workplace']. Digitala skrifter från Nordiska språk 2. Uppsala: Uppsala universitet.

Baba, Marietta L., Carla Dahl-Jørgensen 2013. Language policy in practice: Rebordering the nation. - International Migration 51 (2), 61-76. https://doi. org/10.1111/imig. 12048

Busch, Brigitta 2017. Expanding the notion of the linguistic repertoire: On the concept of Spracherleben - the lived experience of language. - Applied Linguistics 38 (3), 340-358. https://doi.org/10.1093/applin/amv030

Bourdieu, Pierre 1991 [1982]. Language and Symbolic Power. Oxford: Polity Press.

Connell, John 2010. Migration and the Globalization of Health Care. The Health Worker Exodus? Cheltenham: Edward Elgar.

Darvin, Ron, Bonny Norton 2015. Identity and a model of investment in applied linguistics. - Annual Review of Applied Linguistics 35, 35-56. https://doi. org/10.1017/S0267190514000191

Duchêne, Alexandre, Melissa Moyer, Celia Roberts 2013. Introduction: Recasting Institutions and Work in Multilingual and Transnational Spaces. Alexandre Duchêne, Melissa Moyer, Celia Roberts (eds.). Language, Migration and Social Inequalities: A Critical Sociolinguistic Perspective to Institutions and Work. Bristol: Multilingual Matters, 1-21. https://doi. org/10.21832/9781783091010-002

Goffman, Ervin 1983. The interaction order. - American Sociological Review 48 (1), 1-17. https://doi.org/10.2307/2095141

Guest, Greg, Kathleen MacQueen, Emily E. Namey 2012. Applied Thematic Analysis. Thousand Oaks, CA: SAGE. https://doi.org/10.4135/9781483384436 
Gumperz, John J. 1992. Interviewing in Intercultural Situations. - Paul Drew, John Heritage (eds.). Talk at Work: Interaction in Institutional Settings. Cambridge: Cambridge University Press, 302-327.

Hárs, Ágnes, Dávid Simon 2016. A magyarországi orvosok külföldi munkavállalását befolyásoló tényezők ['Factors constraining Hungarian doctors' employment abroad']. - Zsuzsa Blaskó, Károly Fazekas (eds.). Munkaerőpiaci tükör 2015. Budapest: MTA, 96-103. http://real.mtak. hu/37228/1/egyben.pdf (11.10.2021).

Haukilahti, Riitta-Liisa, Irma Virjo, Kari Mattila 2012. ETA-alueen ulkopuolella perustutkintonsa suorittaneiden lääkäreiden Suomeen tulon syyt, työllistyminen ja jatkosuunnitelmat ['The reasons of doctors with basic qualifications from outside the EEA for coming to Finland, their employment and further plans']. - Sosiaalilääketieteellinen aikakauslehti 49, 13-30.

Heller, Monica, Sari Pietikäinen, Joan Pujolar 2018. Critical Sociolinguistic Research Methods: Studying Language Issues that Matter. London: Routledge. https://doi.org/10.4324/9781315739656

Kaelin, Lukas 2011. Care drain: The political making of healthworker migration. Journal of Public Health Policy 32 (4), 489-498. https://doi.org/10.1057/ jphp.2011.43

Kramsch, Claire 2013. Afterword. - Bonny Norton. Identity and Language Learning: Extending the Conversation. Bristol: Multilingual Matters, 192-201. https://doi.org/10.21832/9781783090563-010

Lane, Pia 2014. Nexus analysis. - Jan-Ola Östman, Jef Verschueren (eds.). Handbook of Pragmatics 18. Instalment. https://doi.org/10.1075/hop.18.nex1

Levitt, Peggy, Nina Glick Schiller 2004. Conceptualizing simultaneity: A transnational social field perspective on society. - The International Migration Review 38 (3), 1002-1039. https://doi.org/10.1111/j.1747-7379.2004. tb00227.x

Lundström, Catrin 2017. The white side of migration: Reflections on race, citizenship and belonging in Sweden. - Nordic Journal of Migration Research 7 (2), 79-87. https://doi.org/10.1515/njmr-2017-0014

MEC = Ministry of Education and Culture 2014. Kielitaidon määrittäminen sekä kielitaidon ja EU/ETA-alueen ulkopuolella hankitun koulutuksen täydentäminen terveysalalla ['Assessing language skills and completing language skills and qualifications acquired outside the EU/EEA in healthcare professions']. Reports 2014:5. Helsinki: MEC.

Ministry of Human Resources, Hungary 2018. http://www.enkk.hu/hmr/index. php/migracios-statisztikak/eves-statisztikak (1.4.2020). 
Moyer, Melissa G. 2013. Language as a resource: Migrant agency, positioning and resistance in a health care clinic. - Alexandre Duchêne, Melissa Moyer, Celia Roberts (eds.). Language, Migration and Social Inequalities: A Critical Sociolinguistic Perspective on Institutions and Work. Bristol: Multilingual Matters, 196-224. https://doi.org/10.21832/9781783091010-010

Newton, Jonathan, Ewa Kusmierczyk, 2011. Teaching second languages for the workplace. - Annual Review of Applied Linguistics 31, 74-92. https://doi. org/10.1017/S0267190511000080

NIHW $=$ National Institute for Health and Welfare 2020. Statistical Yearbook on Social Welfare and Health Care 2020. Helsinki: National Institute for Health and Welfare.

Norton Peirce, Bonny 1995. Social identity, investment, and language learning. TESOL Quarterly 29 (1), 9-31. https://doi.org/10.2307/3587803

Norton, Bonny 2016. Identity and language learning: Back to the future. - TESOL Quarterly 50 (2), 475-479. https://doi.org/10.1002/tesq.293

OECD 2019a. Recent Trends in International Migration of Doctors, Nurses and Medical Students. Paris: OECD Publishing. https://doi. org/10.1787/5571ef48-en

OECD 2019b. Health Workforce Migration: Foreign-Trained Doctors by Country of Origin. https://stats.oecd.org/Index.aspx?QueryId=68336 (17.1.2021).

Paananen, Jenny 2019. Yhteisymmärryksen rakentaminen monikulttuurisilla lääkärin vastaanotoilla ['Constructing Mutual Understanding in Multicultural Primary Care Consultations']. Turun yliopiston julkaisuja. Sarja C, Scripta lingua Fennica edita 465. Turku: University of Turku.

Ruuska, Katharina 2020. At the Nexus of Language, Identity and Ideology: Becoming and Being a Highly Proficient Second Language Speaker of Finnish. JYU Dissertations 309. Jyväskylä: University of Jyväskylä. http://urn.fi/ URN:ISBN:978-951-39-8366-6

Sarangi, Srikant 2009. On displacement and engagement: The embedding of applied linguistics and professional practice studies. - Journal of Applied Linguistics 6 (2), 191-215. https://doi.org/10.1558/japl.v6i2.27612

Scollon, Ron, Suzie Wong Scollon 2003. Discourses in Place: Language in the Material World. New York: Routledge. https://doi.org/10.4324/9780203422724

Scollon, Ron, Sue W.Scollon 2004. Nexus Analysis: Discourse and the Emerging Internet. London: Routledge. https://doi.org/10.4324/9780203694343

Seilonen, Marja, Minna Suni, Marita Härmälä, Reeta Neittaanmäki 2016. Ammatillisen kielitaidon arviointikokeilu terveydenhuollon alalla ['Assessment of professional Finnish language proficiency in health sector']. - Ari Huhta, 
Raili Hildén (toim.). Kielitaidon arviointitutkimus 2000-luvun Suomessa. AFinLA-e: Soveltavan kielitieteen tutkimuksia 9. Jyväskylä: AFinLA, 110141. https://journal.fi/afinla/article/view/60850

Socialstyrelsen 2017. Educated within EU or EEA. https://legitimation.socialstyrelsen.se/en/educated-within-eu-or-eea (17.1.2020).

Strömmer, Maiju 2016. Affordances and constraints: Second language learning in cleaning work. - Multilingua: Journal of Cross-Cultural and Interlanguage Communication 35 (6), 403-427. https://doi.org/10.1515/multi-20140113

Strömmer, Maiju 2017. Work-related language learning trajectories of migrant cleaners in Finland. - Apples - Journal of Applied Language Studies 11 (4), 137-160. https://doi.org/10.17011/apples/urn.201712214863

Suni, Minna 2017. Working and learning in a new niche: Ecological interpretations of work-related migration. - Jo Angori, Meredith Marra, Janet Holmes (eds.). Negotiating Boundaries at Work: Talking and Transitions. Edinburgh: Edinburgh University Press, 197-215.

Tervola, Maija 2019. Maahanmuuttajalääkärien suomen kielen taito ja kielitaitotarpeet: Erityisalan kielitaidon näkökulma lääkärin työhön ['Immigrant Physicians' Finnish Language Skills and Language Needs: The Physician's Work from the Perspective of Language Skills for Specific Purposes.] Tampere University Dissertations 92. Tampere: University of Tampere.

Thomas, Felicity (ed.) 2016. The Handbook of Migration and Health. Cheltenham: Edward Elgar Publishing.

van Lier, Leo 2004. Ecology and Semiotics of Language Learning: A Sociocultural Perspective. Boston: Kluwer Academic. https://doi.org/10.1007/1-40207912-5

Valvira 2017. Language requirements. National Supervisory Authority for Welfare and Health. http://www.valvira.fi/en/licensing/professional_practice_ rights/language_requirements (17.1.2020).

Vartiainen, Päivi, Pirkko Pitkänen, Marjuja M. B. Asis, Pirjo Raunio, Marja Koskela 2016. From the Philippines to Finland: Nurses' expectations and Finnish realities. - Journal of Population and Social Studies 24 (1), 30-46. https://doi.org/10.14456/jpss.2016.3

Virtanen, Aija 2017. The multivoicedness of written documentation: An international nursing student documenting in a second language. - European Journal of Applied Linguistics 5 (1), 115-140. https://doi.org/10.1515/ eujal-2015-0015 
NÓRA SCHLEICHER, MINNA SUNI

Wallerstein, Immanuel 2004. World-systems analysis in world system history. George Modelski (ed.). Encyclopedia of Life Support Systems (EOLSS). Paris: Eolss Publishers.

Weedon, Chris 1987. Feminist Practice and Poststructuralist Theory. Oxford: Basil Blackwell. 


\title{
Terveydenhuollon ammattilaiset liikkeellä: työssä tarvittavan kielen oppimiseen investoiminen
}

\author{
NÓRA SCHLEICHER ${ }^{1}$, MINNA SUNI ${ }^{2}$ \\ Budapest Metropolitan yliopisto', Jyväskylän yliopisto²
}

Artikkelissa tarkastellaan maahanmuuton kielikysymyksiä Unkarista Suomeen ja Ruotsiin työllistyneiden terveydenhuollon ammattilaisten näkökulmasta. Neksusanalyyttisessä viitekehyksessä tutkitaan sitä investointia, jonka nämä työntekijät tekevät oppiakseen uutta, työssä tarvitsemaansa kieltä eli suomea tai ruotsia. Tutkimusasetelma on pitkittaiinen, ja analyysi perustuu terveydenhuollon ammattilaisten sekä muutamien kielikoulutuksesta ja rekrytoinnista vastaavien henkilöiden haastatteluihin. Kirjoittajat aloittivat omat tutkimuksesta itsenäisesti mutta yhdistivät voimansa ennen toista aineistonkeruukierrosta. Tämän myötä analyysissa voitiin kattaa useampia kulttuurisia ja ajallisia ulottuvuuksia. Kaiken kaikkiaan kahdeksalle vuodelle yltävä ajanjakso avaakin näkymiä niin valmistautumisvaiheeseen ja kaikkiin niihin pelkoihin ja toiveisiin, joita kuviteltuun tulevaisuuteen liittyy, kuin myös muuton jälkeiseen elettyyn todellisuuteen kahdessa eri Pohjoismaassa ja toisella kielellä työskentelyyn siellä.

Tulokset osoittavat, että suomen tai ruotsin kielen oppimiseen investoiminen kietoutuu tiiviisti maastamuuttopäätökseen. Investoinnin mielekkyys puolestaan todentuu sen myötä, kun legitiimi asema toisen kielen käyttäjänä ja yhteisön jäsenenä vähitellen saavutetaan. Niin aiemmat elämänkokemukset, kansainväliset rekrytointikäytänteet, kielipoliitikka kuin kieli-ideologiatkin vaikuttavat prosessiin. Esimerkiksi aiemmat työolot ja kokemukset kansainvälisestä liikkuvuudesta sekä lähtömaassa tarjottava maksuton kielikoulutus vaikuttavat ratkaisevasti muuttopäätökseen. Sekä viralliset että käytännön ammatillisessa arjessa koetut kielitaitovaatimukset ovat niin ikään merkittäviä tekijöitä: stressiä ja riittämättömyyden tunteita koetaan etenkin alussa jopa sinä määrin, että osa päätyy luovuttamaan. Toisaalta työskentely toisella kielellä käy koko ajan sujuvammaksi; tietoisuus oman kielitaidon kehittymisestä ja kollegoilta eri tilanteissa saatu kielellinen tuki koetaan erityisen merkityksellisiksi. 
NÓRA SCHLEICHER, MINNA SUNI

Työpaikan vuorovaikutustilanteet ovatkin keskeisesti muovaamassa yksilöiden ammatti-identiteettiä työperusteisen maahanmuuton kontekstissa.

Keywords: työperusteinen maahanmuutto; investointi; ammatielämä; neksusanalyysi; toinen kieli; unkari; suomi; ruotsi 


\title{
Vándorló egészségügyi szakemberek: befektetés a munkahelyen szükséges új nyelv elsajátításába
}

\author{
NÓRA SCHLEICHER ${ }^{1}$, MINNA SUNI ${ }^{2}$ \\ Budapesti Metropolitan Egyetem', Jyväskyläi Egyetem²
}

A cikk a migrációval kapcsolatos nyelvi kérdéseket vizsgálja a Magyarországról Finnországba és Svédországba vándorló egészségügyi dolgozók szemszögéből. A nexusanalízis keretrendszerében a munkahelyen szükséges új nyelv, azaz a finn vagy a svéd elsajátításához szükséges befektetéseket kutatjuk. A longitudinális kutatás az egészségügyi szakemberekkel és a nyelvoktatásért és a toborzásért felelős személyekkel készített interjúkon alapul. A szerzők önállóan kezdték el kutatásaikat, együttmüködésük a második adatgyüjtési kör előtt kezdődött. Ez lehetővé tette, hogy több kulturális és időbeli dimenziót is lefedjenek az elemzésben. Az összesen nyolcéves időszak vizsgálata betekintést enged a költözés előtti felkészülési szakaszba és az elképzelt jövővel kapcsolatos félelmekbe és reményekbe, valamint a két északi országban letelepedett és ott új nyelven dolgozó egészségügyi dolgozók megélt valóságába.

Az eredmények azt mutatják, hogy a finn vagy svéd nyelv tanulásába való befektetés szorosan összefonódik a migrációs döntéssel. A beruházás pedig akkor térül meg, amikor a bevándorlók az új nyelv használójaként fokozatosan a közösség legitim tagjává válnak. A korábbi élettapasztalatok, a nemzetközi toborzási gyakorlatok, a nyelvpolitika és a nyelvi ideológiák mind hatnak a folyamatra. A korábbi munkakörülmények és a nemzetközi mobilitás tapasztalatai, valamint az ingyenes nyelvi képzés elérhetősége a származási országban például jelentősen befolyásolják a költözésre irányuló döntést. A nyelvtudásra vonatkozó formális követelmények és a gyakorlati szakmai életben tapasztalt elvárások is fontos tényezők. A stressz és az elégtelenség érzése különösen a kezdetekben tapasztalható olyan mértékben, hogy néhányan feladják terveiket. Másrészt az új nyelven való munka általában egyre gördülékenyebbé válik; ehhez a saját nyelvtudás fejlesztésének tudatosítását és a különböző helyzetekben a kollégáktól kapott nyelvi támogatást különösen relevánsnak tartják a megkérdezettek. 
NÓRA SCHLEICHER, MINNA SUNI

A munkahelyi interakciós helyzetek központi szerepet játszanak a bevándorlók szakmai identitásának alakulásában.

Kulcsszavak: munkaerő-vándorlás; második nyelv; befektetés; munkahelyi élet; nexusanalízis; magyar; finn; svéd

\section{Nóra Schleicher}

Institute of Communication Studies, Budapest Metropolitan University

Nagy Lajos kir. utja 1-9, 1148 Budapest, Hungary

nschleicher@metropolitan.hu

\section{Minna Suni}

University of Jyväskylä, Department of Languages P.O. Box 35

40014 Jyväskylä, Finland

minna.suni@jyu.fi 